\title{
Service Section
}

\section{Case Law of the Court of Justice of the European Union and the General Court}

\author{
Reported Period 01.12.2017-17.04.2018
}

\section{Compiled and edited by Lorenzo Squintani}

Senior Lecturer in European and Economic Law and the University

of Groningen, the Netherlands

l.squintani@rug.nl

\section{Overview of the Judgments ${ }^{1}$}

\section{On the Requirement of Having an Interest to Start Proceeding against EU Law}

Judgment of the Court (Fourth Chamber) of 20 December 2017 in Case C-268/16 $\mathrm{P}$ - Binca Seafoods GmbH

\section{Subject Matter}

This case concerns an appeal by Binca Seafoods GmbH against the judgment of the General Court of 11 March 2016 in case T-94/15, in which the General Court rejected the request of annulment by Binca Seafoods against Commission Implementing Regulation (EU) No. 1358/2014 amending Regulation (EC) No. 889/2008, laying down detailed rules for the implementation of Council Regulation (EC) No. 834/2007, as regards the origin of organic aquaculture animals, aquaculture husbandry practices, feed for organic aquaculture animals and products and substances allowed for use in organic aquaculture. According to the General Court,

1 Only judgements and orders available on Curia.eu under the subject matter 'environment' have been included in this report. 
Binca Seafoods did not have an interest to proceed. The Court of Justice clearly has a different meaning.

\section{Judgment}

The Court of Justice sets aside the order of the General Court of the European Union of 11 March 2016, Binca Seafoods v Commission (T-94/15, E U:T:2016:164) and refers the case back to the General Court of the European Union.

\section{Sharpening the Aarhus Rights}

Judgment of the Court (Second Chamber) of 20 December 2017 in Case C-664/15 - Protect Natur-, Arten- und Landschaftsschutz Umweltorganisation $v$ Bezirkshauptmannschaft Gmünd

On this case see the Case Note by Ch. Sobotta in this JEEPL issue

\section{Subject Matter}

This request for a preliminary ruling concerns the interpretation of Article 4 of Directive 2000/6o/Ec establishing a framework for Community action in the field of water policy (Water framework Directive), and of Article 9(3) of the Aarhus Convention. The request has been made in proceedings between Protect Natur-, Arten- und Landschaftsschutz Umweltorganisation (Protect) and Bezirkshauptmannschaft Gmünd (Gmünd district authority, Austria) concerning Protect's application seeking to secure status as a party to the procedure relating to a request by Aichelberglift Karlstein GmbH for the extension of a permit for a snowmaking facility granted pursuant to legislation governing water-related matters. That authority rejected Protect's request and objections on the ground that it had not claimed that any rights protected under the legislation governing waterrelated matters had been affected, and, for that reason, it could not claim to be a party in the procedure. The national court hearing the case wanted to know, in essence, whether abreach of Article 4 of the Water Framework Directive triggers the applicability of Article 9(3) of the Aarhus Convention. Moreover, it wanted to have clarifications on the meaning of the rights established under the latter provision, and their force to be relied upon to set aside allegedly conflicting national rules.

\section{Key Findings}

41 Since, by its earlier decision, the national competent authority decided, on the basis of an impact assessment in respect of a project on a site protected under Directive 92/43, that that project would not adversely affect the integrity of that site, within the meaning of Article 6(3) of that directive, it could also follow that that project may not have a significant effect 
on the environment within the meaning of Article 6(1)(b) of the Aarhus Convention, so that the later decision, taken in the light of the legislation governing water-related matters, does not fall within the scope of Article 6 of that convention nor, consequently, to that extent, within the scope of Article 9(2) thereof.

42 However, that is so only if the referring court is in a position to satisfy itself that it is, in fact, ruled out that the project at issue may have a significant adverse effect on the state of the water forming the subject of the permit procedure at issue in the main proceedings.

43 It is only if, following its verification, the referring court had to find that such a significant adverse effect was ruled out, that it would follow that the question whether, in the present case, an environmental organisation, such as Protect, has a right to bring proceedings against a decision to grant a permit for a project likely to be contrary to the obligation to prevent the deterioration of the status of water under Article 4 of Directive 2000/6o would have to be assessed in the light of Article 9(3) of the Aarhus Convention.

$5^{2}$ By thus denying environmental organisations any right to bring an action against such a decision to grant a permit, the relevant national procedural law is contrary to the requirements flowing from a combined reading of Article 9(3) of the Aarhus Convention and Article 47 of the Charter.

57 Any provision of a national legal system and any legislative, administrative or judicial practice that might impair the effectiveness of EU law by withholding from the national court with jurisdiction to apply such law the power to do everything necessary at the moment of its application to set aside national legislative provisions that might prevent $\mathrm{EU}$ rules from having full force and effect are incompatible with those requirements, which are the very essence of Eu law (see, inter alia, judgments of 9 March 1978, Simmenthal, 106/77, EU:C:1978:49, paragraph 22, and of 5 April 2016, PFE, C 689/13, EU:C:2016:199, paragraph 41 and the case-law cited).

81 Having regard to the foregoing, the answer to the second question is that the combined provisions of Article 9(3) of the Aarhus Convention, Article 47 of the Charter and Article 14(1) of Directive 2000/60 must be interpreted as precluding national procedural rules that deprive, in situations such as that in question in the main action, environmental organisations of the right to participate, as a party to the procedure, in a permit procedure that is intended to implement Directive 2000/60 and limit the right to bring proceedings contesting decisions resulting from such procedure solely to persons who do have that status.

101 Having regard to the foregoing, the answer to the third question is that, subject to verification by the referring court of the relevant matters of 
fact and national law, Article 9(3) and (4) of the Aarhus Convention, read in conjunction with Article 47 of the Charter, must be interpreted as precluding, in a situation such as that in question in the main action, a national procedural rule that imposes a time limit on an environmental organisation, pursuant to which a person loses the status of party to the procedure and therefore cannot bring an action against the decision resulting from that procedure if it failed to submit objections in good time following the opening of the administrative procedure and, at the very latest, during the oral phase of that procedure.

\section{Liquid Waste and the Meaning of Emissions under the ETS Directive}

Judgment of the Court (Sixth Chamber) of 18 January 2018 in Case C-58/17 INEOS Köln GmbHv Bundesrepublik Deutschland

\section{Subject Matter}

This request for a preliminary ruling concerns the interpretation of Article $3(h)$ of Commission Decision 2011/278/EU determining transitional Union-wide rules for harmonised free allocation of emission allowances pursuant to Article 1oa of the ETS Directive. The request has been made in the course of proceedings between INEOS Köln GMbH ('INEOS') and Germany, concerning the rejection of the application made by INEOS for a free allocation of greenhouse gas emission allowances, insofar as that application concerns emissions stemming from the combustion of incompletely oxidised carbon contained in liquid waste. The national court wanted to know, in essence, whether liquid waste is covered by the ETS Directive.

\section{Key Findings}

49 In those circumstances, while it is fully in compliance with the objectives pursued by Directive 2003/87 and Decision 2011/278 to take into account greenhouse gases generated by the combustion of waste gases containing incompletely oxidised carbon, since those emissions cannot be avoided and the combustion of those waste gases generally results in their reduction, it would, by contrast, go against those objectives to take into account greenhouse gases generated by the combustion of liquid waste containing incompletely oxidised carbon because this would result in an increase of those emissions, even though they are avoidable.

50 Consequently, it follows both from the general scheme of Directive 2003/87 and of Decision 2011/278 and from the objectives which they 
pursue that the emissions generated by the combustion of incompletely oxidised carbon contained in liquid waste cannot be taken into account in respect of process emissions, within the meaning of Article $3(\mathrm{~h})(\mathrm{iv})$ of Decision 2011/278, for the purpose of the free allocation of emission allowances pursuant to Article 10 of that decision.

$51 \quad$ Having regard to the foregoing, the answer to the question referred is that Article $3(\mathrm{~h})$ of Decision 2011/278 must be interpreted as not precluding national legislation, such as that at issue in the main proceedings, which excludes from the concept of 'process emissions sub-installation', within the meaning of that provision, greenhouse gas emissions stemming from the combustion of incompletely oxidised carbon in a liquid state

\section{On Greece Persisted Failure to Comply with the EU Provisions on Urban Waste-Water Treatment}

Judgment of the Court (Third Chamber) of 22 February 2018 in Case C-328/16 European Commission $v$ Hellenic Republic

\section{Subject Matter}

This infringement procedure concerns Greece's failure to adopt the measures necessary to comply with the judgment of 24 June 2004, Commission $v$ Greece (C-119/o2), in which the Court held that, by not taking the measures necessary for the installation of a collecting system for urban waste water from the Thriasio Pedio area and not subjecting urban waste water from that area to treatment more stringent than secondary treatment before its discharge into the sensitive area of the Gulf of Eleusina, the Hellenic Republic has failed to fulfil its obligations under the second subparagraph of Article 3(1) and Article 5(2) of Directive 91/27ı. The Commission accordingly requested the imposition of pecuniar penalties.

\section{Judgment}

1. The court declares that, by failing to adopt the measures necessary to comply with the judgment of 24 June 2004, Commission v Greece (C-119/o2, not published, EU:C:2004:385), the Hellenic Republic failed to fulfil its obligations under Article 260(1) TFEU;

2. Orders that, if the failure to fulfil obligations found in point 1 has continued until the day of delivery of the present judgment, the Hellenic Republic be required to pay to the European Commission a penalty payment of EUR 3276 ooo for each six-month period of delay in implementing the 
measures necessary to comply with the judgment of 24 June 2004, Commission $\mathrm{v}$ Greece (C-119/o2, not published, EU:C:2004:385), from the date of delivery of the present judgment until the judgment of 24 June 2004, Commission v Greece (C-119/02, not published, EU:C:2004:385), has been complied with in full, the actual amount of which must be calculated at the end of each six-month period by reducing the total amount relating to each of those periods by a percentage corresponding to the proportion representing the number of population equivalent units that have actually been brought into compliance with the judgment of 24 June 2004, Commission v Greece (C-119/02, not published, EU:C:2004:385), in the Thriasio Pedio area, at the end of the period in question, in comparison to the number of population equivalent units that have not been brought into compliance with the judgment of 24June 2004, Commission v Greece (C-119/o2, not published, EU:C:2004:385), on the day of delivery of the present judgment;

3. Orders the Hellenic Republic to pay to the European Commission a lump sum of EUR 5 million

\section{On Cleaner Air for Polish Inhabitants}

Judgment of the Court (Third Chamber) of 22 February 2018 in Case C-336/16 European Commission $v$ Republic of Poland

\section{Subject Matter}

By its application, the European Commission asked the Court to declare that the Republic of Poland has failed to fulfil its obligations under, respectively, Articles 13(7), 22(3) and 23(1) of Directive 2008/50/EC. According to the Commission, indeed, since 2007 and up to at least 2013, the daily limit values for particulate matter $P M^{10}$ were exceeded in 35 zones for the assessment and management of ambient air quality and the annual limit values for $P M^{10}$ were exceeded in 9 zones for the assessment and management of ambient air quality, and no information has been provided to indicate that this situation has improved. Moreover, no appropriate measures had been adopted, in ambient air quality programmes, to ensure that the exceedance period of $P M^{10}$ limit values is kept as short as possible. Besides, the daily limit values, increased by the margin of tolerance, were exceeded from 1 January 2010 to 10 June 2011 in three zones, as well as from 1 January 2011 to 10 June 2011 in Ostrów-Kępno. Finally, the second subparagraph of Article 23(1) of the Directive was not correctly implemented. The Court agrees with the Commission on all allegations. 


\section{Judgment}

The Republic of Poland has failed to fulfil its obligations under, respectively, Article 13(1), in conjunction with Annex XI, the second subparagraph of Article 23(1), and Article 22(3) of, in conjunction with Annex XI to, Directive 2008/50/Ec of the European Parliament and of the Council of 21 May 2008 on ambient air quality and cleaner air for Europe, for the following reasons:

- since 2007 and up to 2015 inclusive, the daily limit values for particulate matter $\mathrm{PM}^{10}$ concentrations were exceeded in 35 zones for the assessment and management of ambient air quality and the annual limit values for particulate matter $\mathrm{PM}^{10}$ concentrations were exceeded in 9 zones for the assessment and management of ambient air quality;

- no appropriate measures have been incorporated in ambient air quality programmes to ensure that the exceedance period of particulate matter $\mathrm{PM}^{10}$ concentrations limit values is kept as short as possible;

- the daily limit values for particulate matter $\mathrm{PM}^{10}$ concentrations in ambient air, increased by the margin of tolerance, were exceeded from 1 January 2010 to 10 June 2011 in the Radom, Pruszków-Żyrardów, Kędzierzyn-Koźle zones, as well as from 1 January 2011 to 10 June 2011 in the Ostrów-Kępno zone; and

- the second subparagraph of Article 23(1) of Directive 2008/50 was not correctly implemented.

\section{On the Compatibility of National Procedures for the Correction of Emission Allowances Applications under the ETs Directive}

Judgment of the Court (First Chamber) of 22 February 2018 in Case C-572/16 INEOS Köln GmbHv Bundesrepublik Deutschland

\section{Subject Matter}

This request for a preliminary ruling concerns the interpretation of Article $10 a$ of the ETS Directive, and of Commission Decision 2011/278/EU determining transitional Union-wide rules for harmonised free allocation of emission. The request has been made in proceedings between INEOS Köln GmbH ('INEOS') and Germany, concerning the refusal to allow that company to correct an application for free allocation of greenhouse gas emission allowances ('the emission allowances') for the third trading period 2013-2020. The national court hearing the case wanted to know, in essence, whether the Directive precludes national law setting a limitation period upon the expiry of which the applicant is deprived of any possibility to correct or complete his application. 


\section{Key Findings}

41 In that regard, it should be noted that Article 7(8) of Decision 2011/278 specifies that, where data is missing, Member States are to require the operator to justify any 'lack of data' and to substitute 'partly available data' with conservative estimates, without, however, establishing a procedure that would make it possible to correct or supplement the information provided. Similarly, while Article 8 of that decision prohibits Member States from accepting data that have not been verified as satisfactory by a verifier, that provision does not establish a time limit or a procedure for correcting unsatisfactory data.

42 In those circumstances, in the absence of EU rules concerning the procedural requirements attaching to the submission and examination of an application for free allocation of emission allowances, it is, according to established case-law, for the domestic legal system of each Member State to determine those requirements in accordance with the principle of procedural autonomy provided, however, that those requirements are not less favourable than those governing similar domestic situations (principle of equivalence) and that they do not render impossible in practice or excessively difficult the exercise of rights conferred by the EU legal order (principle of effectiveness) (see, to that effect, inter alia, judgment of 20 October 2016, Danqua, C-429/15, EU:C:2016:789, paragraph 29).

55 It follows that there is nothing in the documents before the Court to suggest that such a mandatory time limit is liable to render impossible in practice or excessively difficult the submission of an application for free allocation of emission allowances for the purpose of exercising the right to obtain free emission allowances under Article 10a of Directive 2003/87 and Decision 2011/278.

\section{On Direct and Indirect Emissions under the ETs Directive}

Judgment of the Court (First Chamber) of 28 February 2018 in Case C-577/16 Trinseo Deutschland Anlagengesellschaft mbHv Bundesrepublik Deutschland

\section{Subject Matter}

This request for a preliminary ruling concerns the interpretation of Article 1 of the ETS Directive and Commission Decision 2011/278/EU of 27 April 2011 determining transitional Union-wide rules for harmonised free allocation of emission allowances. The request has been made in proceedings between Trinseo Deutschland Anlagengesellschaft mbH ('Trinseo') and Germany, concerning the refusal to allocate greenhouse gas emission allowances free of charge to an installation for 
the production of polycarbonate, on the ground that that installation obtains the steam needed for that production from a plant which is operated, on the same site, by another company, Dow Deutschland Anlagengesellschaft, which is subject to the emission allowance trading scheme established by the Directive. The national court hearing the case wanted to know, in essence, whether Trinseo's installation falls within the scope of the ETs Directive.

\section{Key Findings}

49 In the present case, it is apparent from the evidence submitted to the Court, and it is common ground between all the interested parties who have participated in these proceedings, that an installation for the production of polymers, such as that at issue in the main proceedings, which obtains the heat needed for polymerisation from a third-party installation does not itself generate releases of $\mathrm{CO}^{2}$ into the atmosphere, only the production of heat by that latter installation giving rise to such releases. The polymerisation process does not release $\mathrm{CO}^{2}$ since carbon, as the Netherlands Government explained, is specifically necessary for the production of polymers, such as polycarbonate.

50 It follows that the production of polymers by an installation, such as that at issue in the main proceedings, which does not produce, in an integrated manner, the heat needed for polymerisation, does not generate direct emissions of $\mathrm{CO}^{2}$.

51 Or, in the absence of such emissions, an activity, even if it is referred to in Annex I to Directive 2003/87, cannot fall within the scope of that directive and, therefore, of the emissions allowance trading scheme established by that directive.

53 Trinseo and the Commission submit, however, that emissions arising from the production of polymers should include 'indirect' emissions from the production of heat by the third-party installation supplying that heat for the purposes of polymerisation. In their view, that approach is consistent with the objective pursued by Directive $2003 / 87$, inasmuch as it would make it possible to encourage investments aimed at reducing energy consumption. They argue that that approach is also supported by Article 10a of that directive and Article 3(c) and recitals 6 and 21 of Decision $2011 / 278$, which provide for the free allocation of emission allowances to the installation which uses the heat and not to the installation which produces it. Thus, they contend that it is apparent from Article 1(1) of Decision 2013/448, read in conjunction with point E of Annex I to that decision and construed in the light of recitals 16 and 17 of that decision, that polymerisation installations, rather than the heat supplier, must be allocated emission allowances free of charge. They state that Annex I to 
Decision 2011/278 moreover sets benchmarks for products manufactured exclusively in that type of installation.

54 That interpretation cannot be accepted, however.

57 It is thus clearly apparent from that provision that only emissions arising directly from the activity carried out by the installation itself producing the heat can be taken into account in order to determine whether that activity falls within the emissions allowance trading scheme.

$5^{8}$ It follows that $\mathrm{CO}^{2}$ emissions arising from the activity of producing heat justify solely the inclusion in that scheme of installations that are the source of those emissions, such as, in the present case, the thirdparty installation supplying heat to the installation at issue in the main proceedings.

60 It is thus clearly apparent from that wording that an operator which imports heat from a third-party installation cannot rely on the emissions generated by the latter.

\section{On the Duty to Perform an Environmental Impact Assessment after a Project Has Been Realized}

Judgment of the Court (Sixth Chamber) of 28 February 2018 in Case C-117/17 Comune di Castelbellino v Regione Marche

\section{Subject Matter}

This request for a preliminary ruling concerns the interpretation of Directive 2011/92/EU on the assessment of the effects of certain public and private projects on the environment. The request has been made in proceedings between, on the one hand, the Comune di Castelbellino (municipality of Castelbellino, Italy) and, on the other hand, the Regione Marche (Marche Region, Italy), and other Italian authorities, concerning the decision by which the Marche Region took the view that there was no need to examine whether it was necessary to subject the project of Società Agricola ${ }_{4}$ C S. S. (' 4 C'), by which it sought to increase the capacity of a plant for the production of electricity from biogas, to an environmental impact assessment. The increase in question already had been carried out at the time of the municipality of Castelbellino's request. The national court wanted to know, in essence, whether an EIA was still required.

\section{Key Findings}

$3^{0}$ Nevertheless, it should be borne in mind that the Court has previously held, in paragraph 43 of the judgment of 26 July 2017, Comune di Corridonia and Others (C-196/16 and C-197/16, EU:C:2017:589), that, in the 
event of failure to carry out an EIA required by EU law, Member States must nullify the unlawful consequences of that failure, and that EU law does not preclude regularisation through the conducting of an impact assessment after the plant concerned has been constructed and has entered into operation, subject to the twofold condition that, first, national rules allowing for that regularisation do not provide the parties concerned with an opportunity to circumvent the rules of EU law or to dispense with applying them, and second, an assessment carried out for regularisation purposes is not conducted solely in respect of the plant's future environmental impact, but also takes into account its environmental impact from the time of its completion.

$3^{2}$ As a result, under those conditions, where a project has not been subject to a preliminary assessment of the need for an EIA pursuant to provisions incompatible with Directive 2011/92, EU law does not preclude the competent authorities carrying out an assessment of the project, even after its completion, for the purpose of establishing whether or not it must undergo an EIA, where appropriate, on the basis of new national legislation, provided that legislation is compatible with the directive.

\section{On the Concept of 'Environmental Law' under the Aarhus Regulation in Relation to Genetically Modified Organisms}

Judgment of the General Court (Seventh Chamber) of 14 March 2018 in Case T-33/16 - TestBioTech eVv European Commission

\section{Subject Matter}

This case concerns an action for annulment of the letter from the Commissioner for Health and Food Safety of 16 November 2015 rejecting an application for internal review, based on Article 10 of Regulation (EC) No 1367/2006 (the Aarhus Regulation), of implementing decisions authorising the placing on the market of the genetically modified soybeans MON 87769, MON 87705 and 305423 .

\section{Key Findings}

69 It follows that environmental law, within the meaning of Regulation No $1367 / 2006$, covers, in this case, any provision of Eu legislation, concerning the regulation of genetically modified organisms, that has the objective of dealing with a risk, to human or animal health, that originates in those genetically modified organisms or in environmental factors that may have effects on those organisms when they are cultivated or bred in the natural environment. That finding is no less applicable in situations 
where the genetically modified organisms have not been cultivated within the European Union.

76 It follows that concerns with respect to human and animal health, expressed in relation to the lack of appropriate monitoring in this case, also fall within the scope of Article 10 of Regulation No 1367/2006.

77 Consequently, the Commission was wrong to conclude, in the contested decision, that the arguments set out in paragraph 70 above could not be examined within the framework of Article 10 of Regulation No 1367/2006. That finding is not called into question by the other arguments submitted by the Commission and by the interveners.

89 In the light of all the foregoing, it must be concluded that the Commission, in finding that the greater part of the complaints raised by the applicant in its request for internal review did not fall within the scope of environmental law, erred in law. Consequently, the first plea in law must be upheld and the contested decision must be annulled in its entirety, there being no need to examine the applicant's second plea in law.

\section{On the Concept of 'Polluter' under the Packaging and Packaging Waste Directive}

Judgment of the Court (Ninth Chamber) of 15 March 2018 in Case C-104/17 - sc Cali Esprou SRL $v$ Administraţia Fondului pentru Mediu

\section{Subject Matter}

This request for a preliminary ruling concerns the interpretation of Article 15 of European Parliament and Council Directive 94/62/Ec on packaging and packaging waste. The request has been made in proceedings between SC Cali Esprou SRL and the Administraţia Fondului pentru Mediu (Environment Fund Administration, Romania; 'AFM') concerning the lawfulness of a contribution imposed on Cali Esprou by AFM, calculated on the basis of the packaging which it placed on the Romanian market in 2013 and 2014. Cali Esprou imported the packaging without altering it. The national court hearing the case wanted to know, in essence, whether the lack-of-alteration aspect precluded Cali Esprou to be considered as being a polluter for the purposes of the Directive.

\section{Key Findings}

22 In that regard, it should be noted, on the one hand, that the 'polluterpays' principle, referred to in Article 15 and the 29th recital of Directive $94 / 62$ requires, according to that recital, that 'all those involved in the 
production, use, import and distribution of packaging and packaged products become more aware of the place of packaging waste generation' and 'agree to assume liability'. That principle does not cover only those directly responsible for the production of waste, but has a broader scope. It also covers those who contribute to that production of waste, which includes importers and distributors of packaged products (see, by analogy, judgment of 30 March 2017, vG Čistoća, C-335/16, EU:C:2017:242, paragraph 24 and the case-law cited).

43 It follows from all of the foregoing that Article 15 of Directive 94/62 and the 'polluter-pays' principle which it implements do not preclude national legislation, such as that at issue in the main proceedings, which imposes a contribution on an economic operator which does not make any alteration to the packaging it places on the market, calculated on the basis of the difference in weight between, on the one hand, the quantity of packaging waste corresponding to the minimum targets for energy recovery and recovery by recycling and, on the other, the quantity of packaging waste actually recovered or recycled.

\section{On the Costs of Proceedings of a Premature Challenge under the Aarhus Convention}

Judgment of the Court (First Chamber) of 15 Mach 2018 in Case C-470/16 North East Pylon Pressure Campaign Ltd, Maura Sheehy v An Bord Pleanála

\section{Subject Matter}

This request for a preliminary ruling concerns the interpretation of Article 11 of the EIA Directive and of the Aarhus Convention. The request has been made in proceedings between North East Pylon Pressure Campaign Limited (NEPP) and Maura Sheehy, on the one hand, and An Bord Pleanála, and other Irish authorities, on the other, concerning the determination of costs associated with the rejection of an application for judicial review of the development consent process for the installation of an electricity interconnector. On 4 March 2016, NEPP and Ms Sheehy sought to challenge the development consent process, in particular by attempting to prevent the oral hearing being held. To that end, they made an application for leave to seek judicial review and for an interlocutory injunction. The application was dismissed and the national court hearing the case wanted to know, in essence, how to allocate the about 500.000 Euro costs made in that context and what obligation derives from $E U$ law and the Aarhus Convention in that regard. 


\section{Key Findings}

31 It follows that, where national procedural law provides that leave must be sought before bringing a challenge covered by the requirement laid down by Article 11(4) of Directive 2011/92, the costs incurred in a procedure for obtaining that leave must also be covered.

33 It is irrelevant, in that regard, that the application for leave to apply for judicial review was submitted in the course of a process which may lead to the grant of development consent, and not against a final decision closing that process. As pointed out by the Advocate General in points 101 to 108 of his Opinion, Directive 2011/92 neither requires nor prohibits that challenges covered by the guarantee against prohibitive expense be brought against decisions definitively closing a consent process, given the wide range of different environmental decision-making processes, but only stipulates that Member States must determine the stage at which a challenge may be brought.

44 It follows from the foregoing that the answer to the second question is that, where an applicant raises both pleas alleging infringement of the rules on public participation in decision-making in environmental matters and pleas alleging infringement of other rules, the requirement that certain judicial procedures not be prohibitively expensive laid down in Article 11(4) of Directive 2011/92 applies only to the costs relating to the part of the challenge alleging infringement of the rules on public participation.

$5^{8}$ It follows from the foregoing that the answer to the fourth and fifth questions is that Article 9(3) and (4) of the Aarhus Convention must be interpreted as meaning that, in order to ensure effective judicial protection in the fields covered by Eu environmental law, the requirement that certain judicial procedures not be prohibitively expensive applies to the part of a challenge that would not be covered by that requirement, as it results, under Directive 2011/92, from the answer given to the second question, in so far as the applicant seeks, by that challenge, to ensure that national environmental law is complied with. Those provisions do not have direct effect, but it is for the national court to give an interpretation of national procedural law which, to the fullest extent possible, is consistent with them.

65 Accordingly, the answer to the sixth and seventh questions is that a Member State cannot derogate from the requirement that certain judicial procedures not be prohibitively expensive, laid down by Article 9(4) of the Aarhus Convention and Article 11(4) of Directive 2011/92, where a 
challenge is deemed frivolous or vexatious, or where there is no link between the alleged breach of national environmental law and damage to the environment.

\section{On the Compatibility with EU Law of Taxes Imposed upon Emission Allowances under the ETs Directive}

Judgment of the Court (Sixth Chamber) of 12 April 2018 in Case C-302/17 - PPC Power a.s. $v$ Finančné riaditel'stvo Slovenskej republiky

\section{Subject Matter}

This request for a preliminary ruling concerns the interpretation of Article 1 of the ETS Directive. The request has been made in proceedings between PPC Power a.s. and the Daňový úrad pre vybrané daňové subjekty (Tax administration for certain taxpayers, Slovakia; 'the DU') concerning the advance payment of tax on greenhouse gas emission allowances allocated free of charge which have not been used or have been transferred. DU levied a tax on emission allowances for the years 2011 and 2012 at a rate of $80 \%$. The national court hearing the case wanted to know, in essence, whether such a tax is compatible with the goals of the Directive.

\section{Key Findings}

25 It is therefore necessary for the proper functioning of that system that a levy taken by a Member State from the economic value of those emission allowances should not diminish the incentive to reduce greenhouse gas emissions to the point of removing it entirely (see, to that effect, judgment of 17 October 2013, Iberdrola and Others, C-566/11, C-567/11, C-580/11, C-591/11, C-620/11 and C-640/11, EU:C:2013:66o, paragraph 58).

26 It is apparent from the documents before the Court that the Slovak tax at issue in the main proceedings affects up to $80 \%$ of the value of the greenhouse gas emission allowances allocated free of charge which have not been used or have been sold.

27 By eliminating virtually all of the economic value of emission allowances, the tax amounts to a negation of the incentive mechanisms underpinning the emission allowance trading system and, consequently, to the removal of the incentives intended to promote the reduction of greenhouse gas emissions. Thus deprived of $80 \%$ of the economic value of the emission allowances, undertakings lose almost all incentive to invest in 
measures to reduce their emissions which enable them to derive profit from the sale of their unused allowances.

28 Thus, it must be held that that tax has the effect of neutralising the principle of the greenhouse gas emission allowances allocated free of charge provided for in Article 10 of Directive 2003/87, and of undermining the objectives pursued by that directive.

\section{On the Relevance of Mitigation Measures under the Preliminary Screening for Appropriate Assessment under the Habitats Directive}

Judgment of the Court (Seventh Chamber) of 12 April 2018 in Case C-323/17 People Over Wind, Peter Sweetman $v$ Coillte Teoranta

\section{Subject Matter}

This request for a preliminary ruling concerns the interpretation of Article 6(3) of the Habitats Directive. The request has been made in proceedings brought by People Over Wind, an environmental $N G O$, and by Peter Sweetman against Coillte Teoranta ('Coillte'), a company owned by the Irish State that operates in the forestry sector, relating to the works necessary to lay the cable connecting a wind farm to the electricity grid. Authorisation for that project was granted without an appropriate assessment under Article 6(3) of the Directive, as mitigation measures were considered during the preliminary screening. The national court hearing the case wanted to know, in essence, whether this is possible.

\section{Key Findings}

25 Thus, Article 6 of the Habitats Directive divides measures into three categories, namely conservation measures, preventive measures and compensatory measures, provided for in Article 6(1), (2) and (4) respectively. It is clear from the wording of Article 6 of the Habitats Directive that that provision contains no reference to any concept of 'mitigating measure' (see, to that effect, judgment of 21 July 2016, Orleans and Others, C-387/15 and C-388/15, EU:C:2016:583, paragraphs 57 and 58 and the case-law cited).

26 It follows that, as is apparent from the reasoning of the request for a preliminary ruling, that the measures which the referring court describes as 'mitigating measures', and which Coillte refers to as 'protective measures', should be understood as denoting measures that are intended to avoid or reduce the harmful effects of the envisaged project on the site concerned.

37 Taking account of such measures at the screening stage would be liable to compromise the practical effect of the Habitats Directive in general, 
and the assessment stage in particular, as the latter stage would be deprived of its purpose and there would be a risk of circumvention of that stage, which constitutes, however, an essential safeguard provided for by the directive.

39 It is, moreover, from Article 6(3) of the Habitats Directive that persons such as the applicants in the main proceedings derive in particular a right to participate in a procedure for the adoption of a decision relating to an application for authorisation of a plan or project likely to have a significant effect on the environment (see, to that effect, judgment of 8 November 2016, Lesoochranárske zoskupenie VLK, C-243/15, EU:C:2016:838, paragraph 49).

40 In the light of all the foregoing considerations, the answer to the question referred is that Article 6(3) of the Habitats Directive must be interpreted as meaning that, in order to determine whether it is necessary to carry out, subsequently, an appropriate assessment of the implications, for a site concerned, of a plan or project, it is not appropriate, at the screening stage, to take account of the measures intended to avoid or reduce the harmful effects of the plan or project on that site.

\section{On the Protection of 'Puszcza Białowieska' Natura 2000 Site}

Judgment of the Court (Grand Chamber) of 17 April 2018 in Case C-441/17 European Commission $v$ Republic of Poland

On this case see the casenote by Ludwig Krämer in this JEE PL issue.

\section{Subject Matter}

By its application, the European Commission requests the Court to declare that the Republic of Poland has failed to fulfil its obligations under the Habitats and Birds Directives by allowing forest management measures resulting in the cutting of several secular trees protected under EU law. The Court agreed with all complains made by the Commission.

\section{Judgment}

The Court of Justice

Declares that the Republic of Poland has failed to fulfil its obligations under:

- Article 6(3) of Council Directive 92/43/EEC of 21 May 1992 on the conservation of natural habitats and of wild fauna and flora, as amended by Council Directive 2013/17/EU of 13 May 2013, by adopting an appendix to the forest management plan for the Białowieża Forest District without ascertaining 
that that appendix would not adversely affect the integrity of the site of Community importance and special protection area PLC200004 Puszcza Białowieska;

- Article 6(1) of Directive 92/43, as amended by Directive 2013/17, and Article 4(1) and (2) of Directive 2009/147/EC of the European Parliament and of the Council of 30 November 2009 on the conservation of wild birds, as amended by Directive 2013/17, by failing to establish the necessary conservation measures corresponding to the ecological requirements of (i) the natural habitat types listed in Annex I to Directive 92/43, as amended by Directive 2013/17, and the species listed in Annex II to that directive, and (ii) the species of birds listed in Annex I to Directive 2009/147, as amended by Directive $2013 / 17$, and the regularly occurring migratory species not listed in that annex, for which the site of Community importance and special protection area PLC200004 Puszcza Białowieska were designated;

- Article 12(1)(a) and (d) of Directive 92/43, as amended by Directive 2013/17, by failing to guarantee the strict protection of certain saproxylic beetles, namely the goldstreifiger beetle (Buprestis splendens), the flat bark beetle (Cucujus cinnaberinus), the false darkling beetle (Phryganophilus ruficollis) and Pytho kolwensis, listed in Annex IV to that directive, that is to say, by failing effectively to prohibit the deliberate killing or disturbance of those beetles or the deterioration or destruction of their breeding sites in the Białowieża Forest District; and

- Article 5(b) and (d) of Directive 2009/147, as amended by Directive 2013/17, by failing to guarantee the protection of the species of birds referred to in Article 1 of that directive, including, in particular, the pygmy owl (Glaucidium passerinum), the boreal owl (Aegolius funereus), the whitebacked woodpecker (Dendrocopos leucotos) and the three-toed woodpecker (Picoides tridactylus), that is to say, by failing to ensure that they will not be killed or disturbed during the period of breeding and rearing and that their nests or eggs will not be deliberately destroyed, damaged or removed in the Białowieża Forest District;

\section{Editor's Appraisal of the Reported Case Law}

By looking at the judgments reported in the selected period two themes can be brought to the fore: (a) the persistent need of clarity about the ETS Directive and (b) the steady but slow progresses in the improvement of the effectiveness of the EU framework for the enforcement of environmental law. Moreover, it 
is striking to see that several key concepts of EU environmental law are still in need of clarification.

To begin with the latter, three cases among those reviewed in this appraisal make me think about what Eliantonio and Grashof wrote in their article 'Wir müssen reden! - We Need to Have a Serious Talk!', published in this journal in 2016. ${ }^{2}$ That contribution highlights the shortcomings in the ability of the EU full system of remedies (with focus in particular on Articles 258 and $267 \mathrm{TFEU}$ ) to clarify the meaning of EU (environmental) law. The Municipality of Castelbellino case $(\mathrm{C}-117 / 17)$, the new People Over Wind and Sweetman case $(\mathrm{C}-323 / 17)$ and the Cali Esprou case (C-104/17) all concern long-standing pieces of $\mathrm{EU}$ environmental law established four lustra ago, or more. Still the meaning of the concept of 'polluter' under the Packaging and Packaging Waste Directive (adopted in 1994), of the obligation to perform an 'environmental impact assessment' under the EIA Directive (adopted in 1985) and of the obligation to perform an appropriate assessment under the Habitats Directive (adopted in 1992) are unclear. This makes me wonder whether EU law is not in need of a serious rethinking about the instruments available to ensure a uniform interpretation and application of EU law. How many more cases and years do we need to wait before legal certainty is ensured in these fields? And what about legal certainty in newer fields, such as the ETS one?

As indicated above, the ETs Directive was one of the main themes discussed in the case law of the Court of Justice analyzed in this appraisal, with four cases presented in this regard. It is true that the Directive has been amended in March this year, ${ }^{3}$ but these cases all deal with long-standing provisions under the Directive, such as the concept of 'emission' covered by the ETs Directive. Indeed, the INEOS Köln case (C-58/17) clarifies that emissions coming from the combustion of liquid waste cannot be allocated for free as this would incentivize the combustion of liquid waste, leading to more greenhouse gases emissions than if that waste is not combusted. Furthermore, according to the Trinseo case (C-577/16), indirect emissions, i.e. emissions emitted by an installation but actually generated by another one, fall outside the scope of the Directive

2 M. Eliantonio and F. Grashof, Wir müssen reden! - We Need to Have a Serious Talk! The Interaction between the Infringement Proceedings and the Preliminary Reference Procedure in Ensuring Compliance with EU Environmental Standards: A Case Study of Trianel, Altrip and Commission v Germany, JEE PL 2016/3-4, pp. 325-349.

3 Directive (EU) 2018/410 of the European Parliament and of the Council of 14 March 2018 amending Directive 2003/87/EC to enhance cost-effective emission reductions and lowcarbon investments, and Decision (EU) 2015/1814, OJ (2019) L 76/3. 
either. This means that only the installation generating the emission is covered by the emission-trading scheme (and thus entitled to free allowances if available). The other two cases on the ETs Directive dealt by in this appraisal concerns the discretionary powers of the Member States under the Directive. In this regard, the INEOS Köln II case (C-572/16) shows that Germany correctly used the discretionary powers left open under the Directive as regards the procedure to correct errors in the application form for free allowances. Differently the PPC Power case (C-302/17) shows that taxing greenhouse gases allowances granted for free and which have not been used or have been transferred at $80 \%$ of their value is a breach of the Directive. This latter judgment makes me think about a recurring discussion in the context of the ETs Directive, that on more stringent protective measures. ${ }^{4}$ This case did not discuss this aspect, at least not explicitly. Still, in abstracto, taxes on greenhouse gases allowances could be a useful additional tool to ensure that participants to the ETS Directive pay a price for their emissions, which is high enough to ensure compliance with the ETS Directive goals. The question is thus whether taxes could be accepted as a form of more stringent protective measure under the Directive. Albeit implicitly, this case shows that the Court of Justice is willing to review such an additional mechanism, and it will do so by first looking at whether such additional measure contributes to the achievement of the goals of the Directive. In the present case, this step led to a negative answer, as the tax only applied upon greenhouse gases allowances that were not used to compensate emissions or transferred. It thus diminished the incentive to reduce greenhouse gas emissions to the point of removing it entirely, according to the Court. The question remains thus open about what would have the Court decided if the tax applied in all cases and, more generally, how the Court will consider other kinds of more stringent protective measures, such as emission performance standards or emission limit values.

As regards the second theme discussed in this appraisal, i.e. the steady but slow progresses in the improvement of the effectiveness of the EU framework

4 In particular, J. Scott, Multi-Level Governance of Climate Change, CCLR 2011/1, p. 27; D. Wyatt \& R. Macrory in a 'legal advice' (2010): Does the EU's Proposed Directive On Industrial Emissions (IPPC) Preclude Member States From Imposing Emission Limits for Co2 Under National Rules Other Than Those Implementing the Proposed Directive?, no longer available on the internet; L. Squintani, J.M. Holwerda \& K.J. de Graaf, 'Regulating greenhouse gas emissions from EU ETS installations: what room is left for the member states?', in: M. Peeters \& M. Stallworthy, Climate Law in EU Member States, towards National Legislation for Climate Protection (2012 EE), pp. 67-88 and, more recently, but in Dutch, T.J. Thurlings, Verhandelbare emissierechten in broeikasgassen, Ph.D. Thesis, Radboud University Nijmegen, 2017, pp. 34-37. 
for the enforcement of environmental law, the appeal case in Binca Seafoods $(\mathrm{C}-268 / 16 \mathrm{P})$ is surely welcome. The fact that the Court corrected the General Court as regards whether decreases of the concurring position of an undertaking due to EU measures suffices to establish an interest in proceeding against that EU measures, a question answered in the negative by the General Court, prevents, indeed, further worsening the position of individuals under the already highly contested annulment procedure. ${ }^{5}$ Similarly, the infringing procedure against Greece (C-328/16) for non-compliance with the judgment of the Court in the context of urban waste water management and that against Poland (C-336/16) in the context of air quality are welcome developments. Although, the latter case shows how long an infringement procedure can take to conclude, the Commission had sent the first notice in 2009, it fits well within the renewed attention of the Commission on this topic. ${ }^{6}$ The most interesting developments in the context of the enforcement of EU environmental law, though, are, on the one hand, those taking place under the Protect case (C-664/15) and the Pylon case (C-470/16) as regards the meaning of the Aarhus rights to access to justice. On the other hand, the infringement procedure against Poland (C-41/17), as regards the Puszcza Białowieska Natura 2000 site, and the related court order in the interim procedure ${ }^{7}$ show an interesting development about the arsenal at the disposal of the Commission in the context of Article $258 \mathrm{TFEU}$. To Christoph Sobotta the honor to open the discussion on the first two cases, and to Ludwig Krämer that of opening the discussion on the latter ones. Enjoy reading!

5 M. van Wolferen, The Limits to the cJEU's Interpretation of Locus Standi, a Theoretical Framework, JCER, 2016(4), pp. 915-930 with further references.

6 As announced in March 2018, the Commission has started an infringement procedure against several Member States, see for the announcement http://europa.eu/rapid/press-release_IP -18-3450_en.htm (accessed May 2018).

7 Case C-441/17 R, European Commission v Republic of Poland, ECLI:E U:C:2017:877. 